\title{
BEHAVIOURAL STUDIES OF FLOATING COLUMN ON FRAMED STRUCTURE
}

\author{
Shiwli Roy ${ }^{1}$, Gargi Danda de ${ }^{2}$ \\ ${ }^{1}$ ME Scholar - BIT Durg, Civil Engg, BIT Durg, CG \\ ${ }^{2}$ Assistant Professor (Civil Engg dept.)
}

\begin{abstract}
RCC concrete column means cement concrete reinforced with steel bars, steel plates, steel mesh etc. to increase the tension withstanding capacity of the structure. The term floating column means that the column is floated between two floors. Various types of structures $\mathrm{G}+3, \mathrm{G}+5$ and $\mathrm{G}+10$ for RCC column and floating column are analyzed. The difference between $\mathrm{G}+3, \mathrm{G}+5$ and $\mathrm{G}+10$ structures are shown by graphs and charts. Comparison will be done on bending moment and shear force between these structures. This paper presents the analysis of floating column and RCC column by using STAAD PRO V8i.
\end{abstract}

Keywords: Floating Column, RCC column shear force and bending moment.

\section{INTRODUCTION}

Column in structural engineering is a structural element that transmits the weight of the structure to its lower structural elements. In other words, compression members are often termed "columns" because of the stress conditions. Columns are frequently used to support beams or arches on which the upper parts of walls or ceilings rest. A column is supposed to be a vertical member starting from foundation level and transferring the load to the ground. The term floating column is also a vertical element which ends (due to architectural design/ site situation) at its lower level (termination Level) rests on a beam which is a horizontal member. The beams in turn transfer the load to other columns below it. Such columns where the load was considered as point load. Theoretically such structures can be analyzed and designed. This paper presents the floating column and RCC column analysis on multistoried building and analyzed by STAAD PRO V8i. Here G+3, G+5 and $\mathrm{G}+10$ structures are analyzed and compared with parameters shear force and bending moment.

\section{BUILDING DESCRIPTION}

The study is carried out on a building with floating columns. The layout of the building is shown in the figure. The building considered is a multistorey building having $\mathrm{G}+3$, $\mathrm{G}+5$ and $\mathrm{G}+10$ structures.

\section{A. $G+3$ Structure}

It is a three storey building with one roof. The span of these structures is $6 \mathrm{~m}$. The length and width of each floor is $3 \mathrm{~m}$. The total height of structure is $12 \mathrm{~m}$. This model has been analyzed by creating fixed support on ground storey, by assigning dead load and live load for floating column and RCC column.
It is a five storey building with one roof. The span of these structures is $6 \mathrm{~m}$. The length and width of each floor is $3 \mathrm{~m}$. The total height of structure is $18 \mathrm{~m}$. This model has been analyzed by creating fixed support on ground storey, by assigning dead load and live load for floating column and RCC column.

\section{C. $G+10$ Structure}

It is a ten storey building with one roof. The span of these structures is $6 \mathrm{~m}$. The length and width of each floor is $3 \mathrm{~m}$. The total height of structure is $36 \mathrm{~m}$. This model has been analyzed by creating fixed support on ground storey, by assigning dead load and live load for floating column and RCC column.

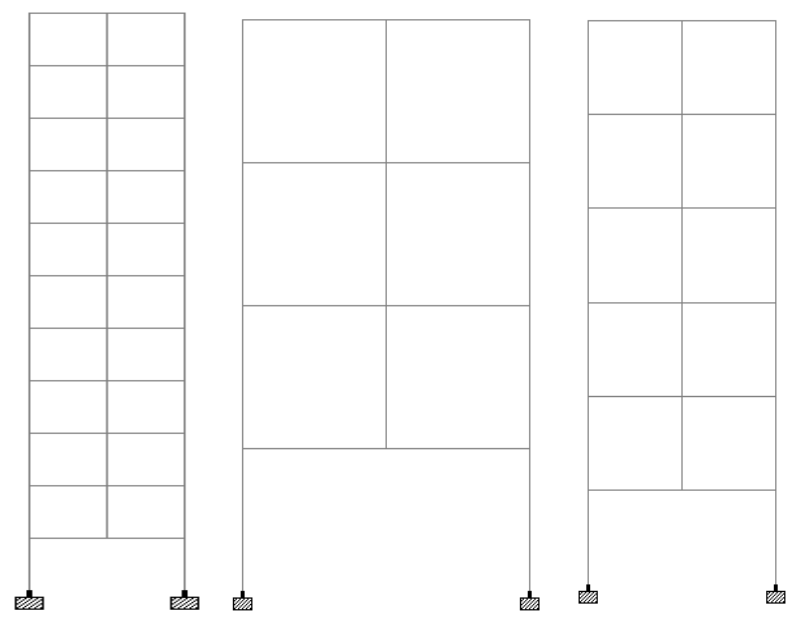

B. G+5 Structure 

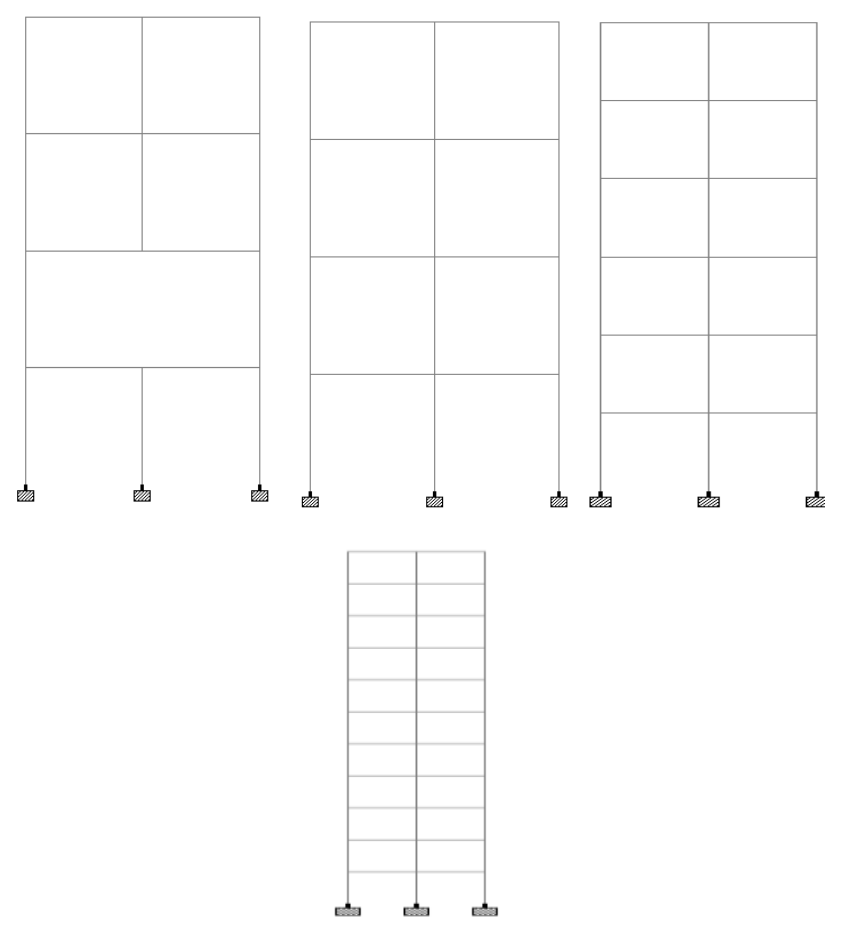

Fig. 1 Front view of $\mathrm{G}+3, \mathrm{G}+5, \mathrm{G}+10$ structures

\section{LOAD COMBINATION}

For design of reinforced concrete structures, the load combination 1.5(DL + LL) should be used. Because in this paper DL and LL loads are only taken into consideration.

\section{LOAD CONSIDERED}

The dead load on which self weight of factor in $\mathrm{Y}$ direction and live load of uniform force $3 \mathrm{KN} / \mathrm{m}$ are assigned on each floor as shown below:
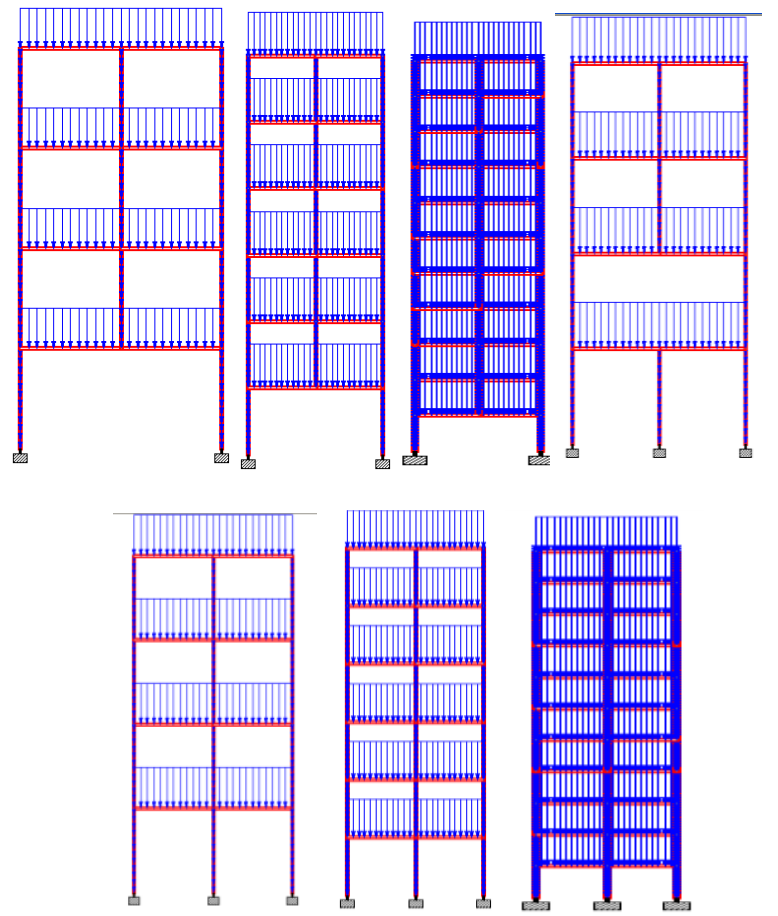

Fig. 2: Loads taken on different Structure

\section{ANALYSIS OF G+3, G+5 AND G+10 STRUCTURES ON STAAD PRO V8I}

\section{A. Analysis on structures}

After the dead load and live load are assigned the analysis on shear force and bending moment are as shown below:

i. Shear force: Shear force of G+3 structure on which ground and first floor column is selected and the table as shown below:

TABLE I

SHEAR FORCE OF NORMAL COLUMN OF G+ 3 STRUCTURES.

\begin{tabular}{|c|c|c|c|c|c|}
\hline ఏ & 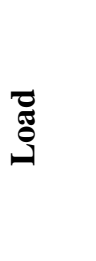 & $\begin{array}{l}\text { 름 } \\
\text { Z }\end{array}$ & 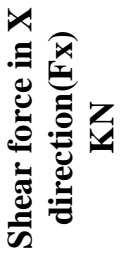 & 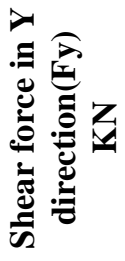 & 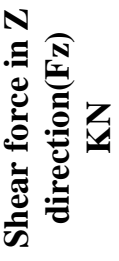 \\
\hline \multirow[t]{4}{*}{77} & $1 \mathrm{DL}$ & 31 & 7.657 & -0.038 & -0.043 \\
\hline & & 34 & -6.738 & 0.038 & 0.043 \\
\hline & $2 \mathrm{LL}$ & 31 & 69.798 & -0.319 & -0.368 \\
\hline & & 34 & 60.798 & 0.319 & 0.368 \\
\hline \multirow[t]{4}{*}{79} & $1 \mathrm{DL}$ & 35 & 7.657 & 0.038 & -0.043 \\
\hline & & 36 & -6.738 & -0.038 & 0.043 \\
\hline & $2 \mathrm{LL}$ & 35 & 69.798 & 0.319 & -0.368 \\
\hline & & 36 & 60.798 & -0.319 & 0.368 \\
\hline
\end{tabular}

TABLE II

SHEAR FORCE OF FLOATING COLUMN OF G+ 3 STRUCTURES.

\begin{tabular}{|c|c|c|c|c|c|}
\hline 主 & 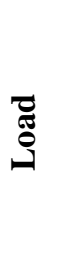 & $\begin{array}{l}\frac{0}{8} \\
\text { Zे }\end{array}$ & 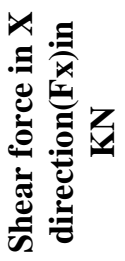 & 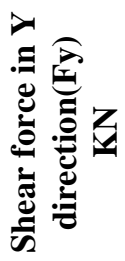 & 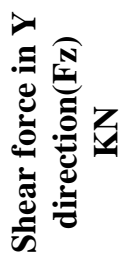 \\
\hline \multirow[t]{2}{*}{12} & $1 \mathrm{DL}$ & 5 & 12.025 & -0.357 & -0.039 \\
\hline & $2 \mathrm{LL}$ & 5 & 110.321 & -3.185 & -0.328 \\
\hline \multirow[t]{2}{*}{79} & $1 \mathrm{DL}$ & 33 & 12.025 & 0.357 & -0.039 \\
\hline & $2 \mathrm{LL}$ & 33 & 110.321 & 3.185 & -0.328 \\
\hline \multirow[t]{2}{*}{25} & $1 \mathrm{DL}$ & 11 & 8.997 & -0.659 & -0.078 \\
\hline & $2 \mathrm{LL}$ & 11 & 82.547 & -5.886 & -0.665 \\
\hline \multirow[t]{2}{*}{84} & $1 \mathrm{DL}$ & 36 & 8.997 & 0.659 & -0.078 \\
\hline & $2 \mathrm{LL}$ & 36 & 82.547 & 5.886 & -0.665 \\
\hline
\end{tabular}


TABLE III

SHEAR FORCE OF FLOATING COLUMN1 OF G+ 3 STRUCTURES

\begin{tabular}{|c|c|c|c|c|c|}
\hline $\begin{array}{l}\text { है } \\
\frac{\text { E }}{0}\end{array}$ & & $\frac{8}{8}$ & 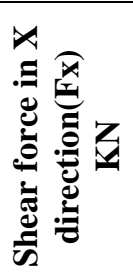 & 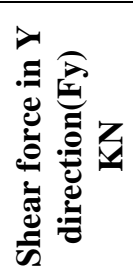 & 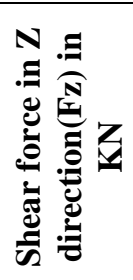 \\
\hline \multirow[t]{2}{*}{77} & $1 \mathrm{DL}$ & 31 & 11.273 & 0.023 & -0.044 \\
\hline & $2 \mathrm{LL}$ & 31 & 101.704 & 0.213 & -0.377 \\
\hline \multirow[t]{2}{*}{79} & $1 \mathrm{DL}$ & 33 & 11.273 & -0.023 & -0.044 \\
\hline & $2 \mathrm{LL}$ & 33 & 101.704 & -0.213 & -0.377 \\
\hline
\end{tabular}

ii. Shear force of $\mathrm{G}+5$ structure on which ground and first floor column is selected and the table as shown below:

TABLE IV

SHEAR FORCE OF G+ 5 STRUCTURES FOR NORMAL COLUMN

\begin{tabular}{|c|c|c|c|c|c|}
\hline & & & \multicolumn{2}{|r|}{ DEC } & \multirow[b]{2}{*}{ 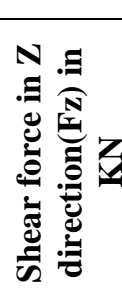 } \\
\hline 訇 & 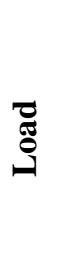 & है & 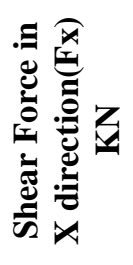 & 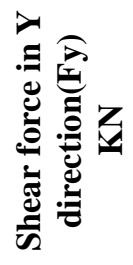 & \\
\hline \multirow[t]{2}{*}{109} & $1 \mathrm{DL}$ & 43 & 11.567 & -0.038 & -0.044 \\
\hline & $2 \mathrm{LL}$ & 43 & 105.387 & -0.323 & -0.372 \\
\hline \multirow[t]{2}{*}{111} & 1DL & 45 & 11.567 & 0.038 & -0.044 \\
\hline & $2 \mathrm{LL}$ & 45 & 105.387 & 0.323 & -0.372 \\
\hline \multirow[t]{2}{*}{114} & $1 \mathrm{DL}$ & 46 & 9.652 & -0.071 & -0.080 \\
\hline & $2 \mathrm{LL}$ & 46 & 87.934 & -0.599 & -0.680 \\
\hline \multirow[t]{2}{*}{116} & $1 \mathrm{DL}$ & 48 & 9.652 & 0.071 & -0.080 \\
\hline & $2 \mathrm{LL}$ & 48 & 87.934 & 0.599 & -0.680 \\
\hline
\end{tabular}

TABLE V

SHEAR FORCE OF G+ 5 STRUCTURES FOR FLOATING COLUMN

\begin{tabular}{|c|c|c|c|c|c|}
\hline$\frac{\bar{E}}{\tilde{E}}$ & 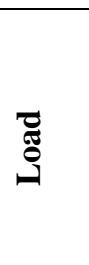 & ஜ & 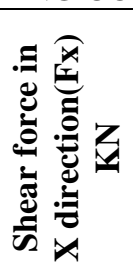 & 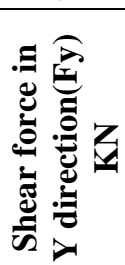 & 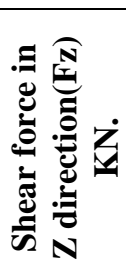 \\
\hline \multirow[t]{2}{*}{109} & $1 \mathrm{DL}$ & 43 & 18.8 & $\begin{array}{l}-0.38 \\
\end{array}$ & -0.041 \\
\hline & $2 \mathrm{LL}$ & 43 & 169.784 & 3.367 & -0.344 \\
\hline \multirow[t]{2}{*}{111} & $1 \mathrm{DL}$ & 45 & 18.8 & 0.38 & -0.041 \\
\hline & $2 \mathrm{LL}$ & 45 & 169.784 & 3.367 & -0.344 \\
\hline \multirow[t]{2}{*}{114} & $1 \mathrm{DL}$ & 46 & 15.660 & -0.693 & -0.080 \\
\hline & $2 \mathrm{LL}$ & 46 & 141.423 & -6.143 & -0.681 \\
\hline \multirow[t]{2}{*}{116} & $1 \mathrm{DL}$ & 48 & 15.660 & 0.693 & -0.080 \\
\hline & $2 \mathrm{LL}$ & 48 & 141.423 & 6.143 & -0.681 \\
\hline
\end{tabular}

iii. Shear force of G+ 10 structures on which ground and first floor columns is selected and table are shown below:
TABLE VI

SHEAR FORCE OF G+ 10 STRUCTURES FOR NORMAL COLUMN

\begin{tabular}{|l|l|l|l|l|l|}
\hline Column & Load & Node & Fx KN & Fy KN & Fz KN \\
\hline 189 & 1 DL & 73 & 21.611 & -0.039 & -0.044 \\
\hline & 2 LL & 73 & 196.642 & -0.327 & -0.378 \\
\hline 191 & 1 DL & 75 & 21.611 & 0.039 & -0.044 \\
\hline & 2 LL & 75 & 196.642 & 0.327 & -0.378 \\
\hline 194 & 1 DL & 76 & 19.691 & -0.072 & -0.082 \\
\hline & 2 LL & 76 & 179.148 & -0.614 & -0.695 \\
\hline 196 & 1 DL & 78 & 19.691 & 0.072 & -0.082 \\
\hline & 2 LL & 78 & 179.148 & 0.614 & -0.695 \\
\hline
\end{tabular}

TABLE VII

SHEAR FORCE OF G+ 10 STRUCTURES FOR FLOATING COLUMN

\begin{tabular}{|l|l|l|l|l|l|}
\hline Column & Load & Node & Fx KN & Fy KN & Fz KN \\
\hline 189 & 1 DL & 73 & 35.404 & -0.413 & -0.041 \\
\hline & 2 LL & 73 & 319.720 & -3.672 & -0.349 \\
\hline 191 & 1 DL & 75 & 35.404 & 0.413 & -0.041 \\
\hline & 2 LL & 75 & 319.720 & 3.672 & -0.349 \\
\hline 194 & 1 DL & 76 & 32.144 & -0.750 & -0.082 \\
\hline \multirow{2}{*}{196} & 2 LL & 76 & 290.266 & -6.660 & -0.699 \\
\hline & 1 DL & 78 & 32.144 & 0.750 & -0.082 \\
\hline & 2 LL & 78 & 290.266 & 6.660 & -0.699 \\
\hline
\end{tabular}

iv. Bending moment: Bending moment diagram of $\mathrm{G}+3$ structure for floating column has been analyzed and on which ground and first floor column is selected and the table is as shown below:

TABLE VIII

BM OF G+ 3 STRUCTURES FOR NORMAL COLUMN

\begin{tabular}{|c|c|c|c|c|c|}
\hline 音 & 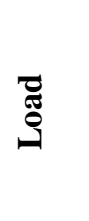 & 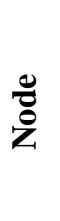 & 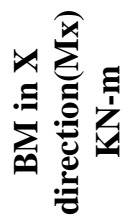 & 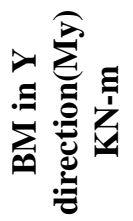 & 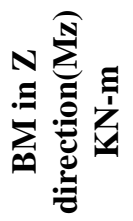 \\
\hline \multirow[t]{4}{*}{77} & $1 \mathrm{DL}$ & 31 & 0 & 0.043 & -0.038 \\
\hline & & 34 & -0 & 0.087 & -0.075 \\
\hline & $2 \mathrm{LL}$ & 31 & -0 & 0.387 & -0.319 \\
\hline & & 34 & 0 & 0.737 & -0.639 \\
\hline \multirow[t]{4}{*}{79} & $1 \mathrm{DL}$ & 33 & 0 & 0.043 & 0.038 \\
\hline & & 36 & -0 & 0.087 & 0.075 \\
\hline & $2 \mathrm{LL}$ & 33 & -0 & 0.387 & 0.319 \\
\hline & & 36 & 0 & 0.737 & 0.639 \\
\hline
\end{tabular}


TABLE IX

BM OF G+ 3 STRUCTURES FOR FLOATING COLUMN ON COLUMNS

\begin{tabular}{|c|c|c|c|c|c|}
\hline 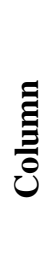 & 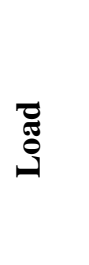 & $\frac{{ }_{0}^{\circ}}{8}$ & 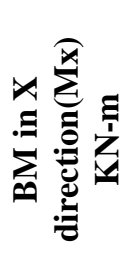 & 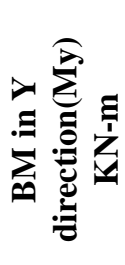 & 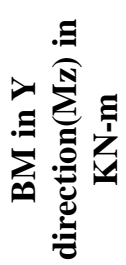 \\
\hline \multirow[t]{2}{*}{12} & $1 \mathrm{DL}$ & 5 & 0.002 & 0.039 & -0.355 \\
\hline & $2 \mathrm{LL}$ & & 0.019 & 0.328 & -3.182 \\
\hline \multirow[t]{2}{*}{79} & $1 \mathrm{DL}$ & 33 & -0.002 & 0.039 & 0.355 \\
\hline & $2 \mathrm{LL}$ & 33 & -0.019 & 0.328 & 3.182 \\
\hline \multirow[t]{2}{*}{25} & $1 \mathrm{DL}$ & 11 & -0.002 & 0.117 & -1.015 \\
\hline & $2 \mathrm{LL}$ & 11 & -0.018 & 0.992 & -9.068 \\
\hline \multirow[t]{2}{*}{84} & $1 \mathrm{DL}$ & 36 & 0.002 & 0.117 & 1.015 \\
\hline & $2 \mathrm{LL}$ & 36 & 0.018 & 0.992 & 9.068 \\
\hline
\end{tabular}

TABLE X

BM OF G+ 3 STRUCTURES FOR FLOATING COLUMN 1 ON COLUMNS

\begin{tabular}{|c|c|c|c|c|c|}
\hline$\frac{\bar{E}}{\frac{\mathrm{E}}{\dot{\theta}}}$ & త్ర్త & $\frac{0}{8}$ & 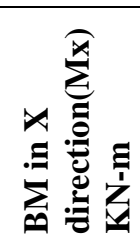 & 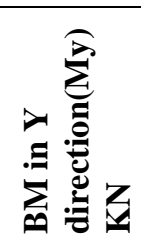 & 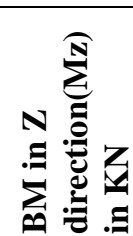 \\
\hline \multirow[t]{2}{*}{77} & $1 \mathrm{DL}$ & 31 & -0 & 0.044 & 0.022 \\
\hline & $2 \mathrm{LL}$ & 31 & -0 & 0.376 & 0.211 \\
\hline \multirow[t]{2}{*}{79} & 1DL & 34 & 0 & 0.044 & -0.022 \\
\hline & $2 \mathrm{LL}$ & 34 & 0 & 0.376 & -0.211 \\
\hline
\end{tabular}

v. Bending moment diagram of $\mathrm{G}+5$ structure for floating column has been analyzed and the on which ground and first floor column is selected as shown below:

TABLE XI

BM OF G+ 5 STRUCTURES FOR NORMAL COLUMN ON COLUMNS

\begin{tabular}{|c|c|c|c|c|c|}
\hline$\frac{\bar{E}}{\underline{\Xi}}$ & ڤ్లై & 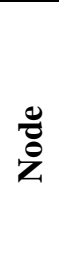 & 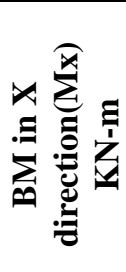 & 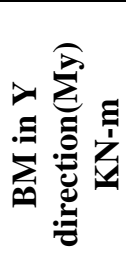 & 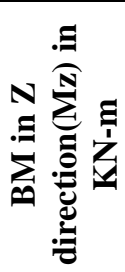 \\
\hline \multirow[t]{2}{*}{109} & $1 \mathrm{DL}$ & 43 & -0 & 0.044 & -0.038 \\
\hline & $2 \mathrm{LL}$ & 43 & -0 & 0.372 & -0.322 \\
\hline \multirow[t]{2}{*}{111} & 1DL & 45 & -0 & 0.044 & 0.038 \\
\hline & $2 \mathrm{LL}$ & 45 & -0 & 0.372 & 0.322 \\
\hline \multirow[t]{2}{*}{114} & $1 \mathrm{DL}$ & 46 & -0 & 0.124 & -0.109 \\
\hline & $2 \mathrm{LL}$ & 46 & -0 & 1.052 & -0.922 \\
\hline \multirow[t]{2}{*}{116} & $1 \mathrm{DL}$ & 48 & -0 & 0.124 & 0.109 \\
\hline & $2 \mathrm{LL}$ & 48 & -0 & 1.052 & 0922 \\
\hline
\end{tabular}

TABLE XII

BM OF G+ 5 STRUCTURES FOR FLOATING COLUMN ON COLUMNS

\begin{tabular}{|c|c|c|c|c|c|}
\hline$\frac{\bar{E}}{\mathrm{E}}$ & 胥 & 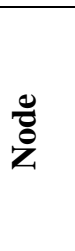 & 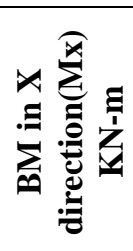 & 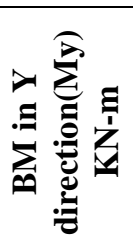 & 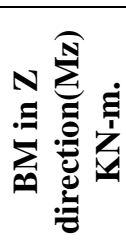 \\
\hline \multirow[t]{2}{*}{109} & $1 \mathrm{DL}$ & 43 & 0.002 & 0.040 & -0.380 \\
\hline & $2 \mathrm{LL}$ & 43 & 0.020 & 0.344 & -3.363 \\
\hline \multirow{2}{*}{111} & $1 \mathrm{DL}$ & 45 & -0.002 & 0.040 & 0.380 \\
\hline & $2 \mathrm{LL}$ & 45 & -0.020 & 0.344 & 3.363 \\
\hline 114 & $1 \mathrm{DL}$ & 46 & -0.002 & 0.121 & -1.073 \\
\hline
\end{tabular}

vi. Bending moment diagram of G+10 Structure for floating column and the on which ground and first floor columns are selected and the results are as follows:

TABLE XIII

BM OF G+ 10 STRUCTURES FOR NORMAL COLUMN ON COLUMNS

\begin{tabular}{|c|c|c|c|c|c|}
\hline Column & Load & Node & $\begin{array}{c}\text { Mx } \\
\text { KN-m }\end{array}$ & $\begin{array}{c}\text { My } \\
\text { KN-m }\end{array}$ & $\begin{array}{c}\text { Mz } \\
\text { KN-m }\end{array}$ \\
\hline \multirow{2}{*}{189} & 1 DL & 73 & -0 & 0.044 & -0.039 \\
\cline { 2 - 6 } & 2 LL & 73 & -0 & 0.377 & -0.327 \\
\hline \multirow{2}{*}{191} & 1 DL & 75 & -0 & 0.044 & 0.039 \\
\cline { 2 - 6 } & 2 LL & 75 & -0 & 0.377 & 0.327 \\
\hline \multirow{2}{*}{194} & 1 DL & 76 & -0 & 0.126 & -0.111 \\
\cline { 2 - 6 } & 2 LL & 76 & -0 & 1.073 & -0.941 \\
\hline \multirow{2}{*}{196} & 1 DL & 78 & -0 & 0.126 & 0.111 \\
\cline { 2 - 6 } & 2 LL & 78 & -0 & 1.073 & 0.941 \\
\hline
\end{tabular}

TABLE XII

BM OF G+ 10 STRUCTURES FOR FLOATING COLUMN ON COLUMNS

\begin{tabular}{|c|c|c|c|c|c|}
\hline Column & Load & Node & $\begin{array}{c}\text { Mx } \\
\text { KN-m }\end{array}$ & $\begin{array}{c}\text { My } \\
\text { KN-m }\end{array}$ & $\begin{array}{c}\text { Mz } \\
\text { KN-m }\end{array}$ \\
\hline 189 & 1 DL & 73 & 0.002 & 0.041 & -0.413 \\
\hline & 2 LL & 73 & 0.020 & 0.349 & -3.668 \\
\hline 191 & 1 DL & 75 & -0.002 & 0.041 & 0.413 \\
\hline & 2 LL & 75 & 0.020 & 0.349 & 3.668 \\
\hline 194 & 1 DL & 76 & -0.002 & 0.123 & -1.163 \\
\hline & 2 LL & 76 & -0.019 & 1.047 & -10.328 \\
\hline 196 & 1 DL & 78 & 0.002 & 0.123 & 1.163 \\
\hline & 2 LL & 78 & 0.019 & 1.047 & 10.328 \\
\hline
\end{tabular}

\section{RESULT AND DISCUSSION}

The G+3, G+5 and G+ 10 structures are compared with tables and graphs of shear force and bending moment as shown below: 
TABLE I

SHEAR FORCE IN X DIRECTION

\begin{tabular}{|c|c|c|}
\hline $\begin{array}{c}\text { Shear force in X } \\
\text { direction in KN }\end{array}$ & Normal column & Floating column \\
\hline $\mathrm{G}+3$ & 7.657 & 12.025 \\
\hline $\mathrm{G}+5$ & 11.567 & 18.7 \\
\hline $\mathrm{G}+10$ & 21.611 & 35.404 \\
\hline
\end{tabular}

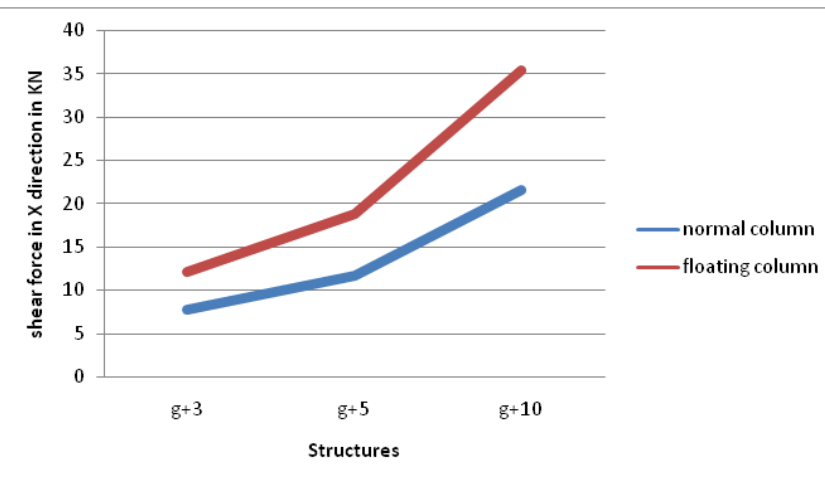

Figure 1: Variation of Shear force in X direction for normal and floating column

The graph shows that the shear force is maximum for floating column but is minimum for normal column. If the shear force in floating column increases the normal column also increases. This means that if the height of structures increases the shear force also increases.

TABLE II

BENDING MOMENT IN Y DIRECTION

\begin{tabular}{|c|c|c|}
\hline $\begin{array}{c}\text { BM in Y direction } \\
\text { in KN-m }\end{array}$ & $\begin{array}{c}\text { Normal } \\
\text { column }\end{array}$ & $\begin{array}{c}\text { Floating } \\
\text { column }\end{array}$ \\
\hline $\mathrm{G}+3$ & 0.043 & 0.039 \\
\hline $\mathrm{G}+5$ & 0.044 & 0.040 \\
\hline $\mathrm{G}+10$ & 0.044 & 0.041 \\
\hline
\end{tabular}

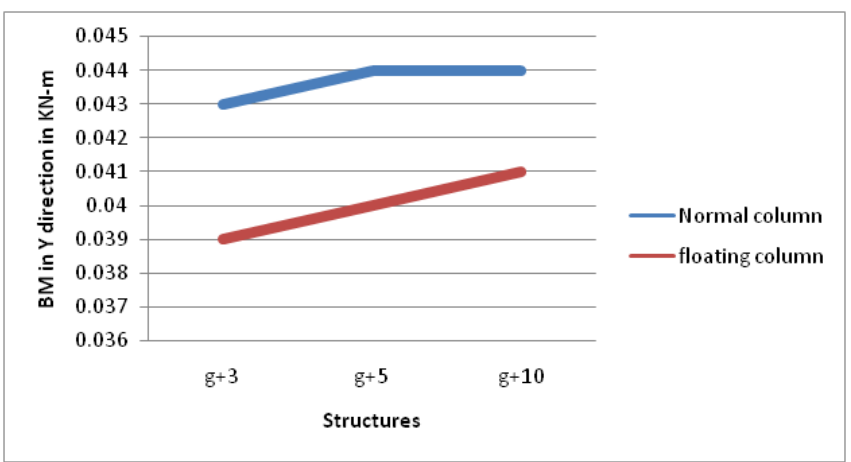

Fig. 2: Variation of bending moment in $\mathrm{Y}$ direction

The graph shows that in $\mathrm{G}+3$ structures the moment is maximum for normal column and the moment is constant in normal column and the moment suddenly increases from $\mathrm{G}+3$ to $\mathrm{G}+10$ structures. This means that the moment for floating column increases with increase in its structure increases.

Comparison of Shear force and bending moment of $\mathrm{G}+3$ structure in normal column, floating column(column removed from ground floor) and floating column 1(column removed between first floor and second floor) through tables and graphs as shown below:

TABLE III

SHEAR FORCE IN X DIRECTION FOR G+3

STRUCTURE IN NORMAL AND FLOATING COLUMN

\begin{tabular}{|l|l|l|l|}
\hline Column & $\begin{array}{l}\text { G+3(normal } \\
\text { column) }\end{array}$ & $\begin{array}{l}\text { G+3(floating } \\
\text { column) }\end{array}$ & $\begin{array}{l}\text { G+3(floating } \\
\text { column 1) }\end{array}$ \\
\hline Column 1 & 7.657 & 12.025 & 11.273 \\
\hline Column 2 & 5.745 & 8.997 & 9.305 \\
\hline
\end{tabular}

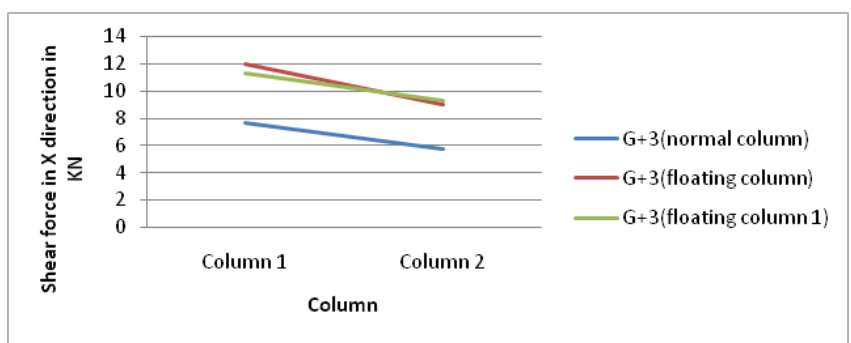

Fig. 3: Variation of shear force in $\mathrm{X}$ direction for $\mathrm{G}+3$ structure in normal and floating column.

TABLE IV

BENDING MOMENT IN Y DIRECTION FOR G+3 STRUCTURE IN NORMAL AND FLOATING COLUMN

\begin{tabular}{|l|l|l|l|}
\hline Column & $\begin{array}{l}\text { G+3(normal } \\
\text { column) }\end{array}$ & $\begin{array}{l}\text { G+3(floating } \\
\text { column) }\end{array}$ & $\begin{array}{l}\text { G+3(floating } \\
\text { column 1) }\end{array}$ \\
\hline Column 1 & 0.043 & 0.039 & 0.044 \\
\hline Column 2 & 0.124 & 0.117 & 0.131 \\
\hline
\end{tabular}

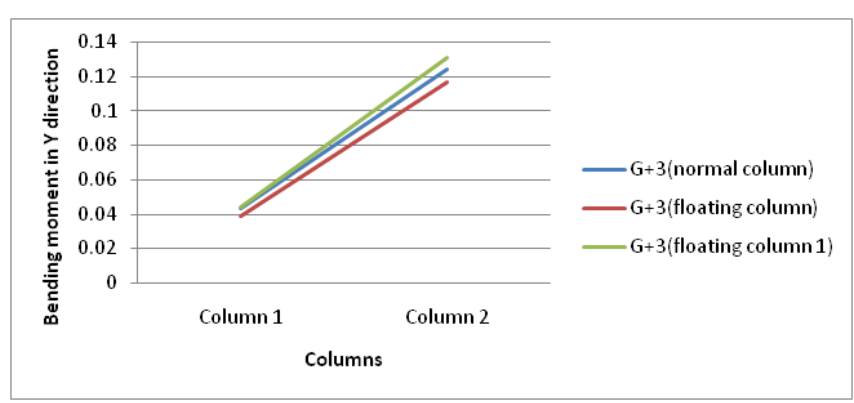

Fig. 4: Variation of Bending moment in Y direction for G+3 structure in normal and floating column

\section{CONCLUSION}

The analysis on floating column for $\mathrm{G}+3, \mathrm{G}+5$ and $\mathrm{G}+10$ structures shows that if the height of the structure increases, the shear force and bending moment also increases.

Following are some conclusion as done on above study:

a) The column shear varies according to the situation and the orientation of columns.

b) The moment at every floor increases and shear force increases but it is same for each floor column.

c) The variation in shear force shows that the shear force is maximum for $\mathrm{G}+10$ structure and the difference between normal and floating column for shear force is 
$4.368 \mathrm{KN}$ for $\mathrm{G}+3$ structure, $7.133 \mathrm{KN}$ for $\mathrm{G}+5$ structure and $13.793 \mathrm{KN}$ for $\mathrm{G}+10$ structure.

d) The variation in shear force shows that the Bending moment is maximum for $\mathrm{G}+10$ structure and the difference between normal and floating column for bending moment is $0.004 \mathrm{KN}$ for $\mathrm{G}+3$ structure, 0.004 $\mathrm{KN}$ for $\mathrm{G}+5$ structure and $0.003 \mathrm{KN}$ for $\mathrm{G}+10$ structure.

e) For comparison between shear force for $\mathrm{G}+3$ structure in normal column, floating column(column removed from ground floor) and floating column 1(column removed between first floor and second floor) the variation in shear force shows that the shear force is maximum in floating column(column removed from ground floor) the shear force increases by $57 \%$ for $\mathrm{G}+3$ (normal column)to $\mathrm{G}+3$ (floating column) structures and $6.67 \%$ for $\mathrm{G}+3$ (floating column) to $\mathrm{G}+3$ ( floating column1)structures in column1(column for ground floor) and in column2(column for first floor) it increases by $56 \%$ for $\mathrm{G}+3$ (normal column) to $\mathrm{G}+3$ (floating column)structures and $3.42 \%$ for $\mathrm{G}+3$ (floating column) to $\mathrm{G}+3$ ( floating column1)structures.

f) For comparison between bending moment for $\mathrm{G}+3$ structure in normal column, floating column(column removed from ground floor) and floating column 1(column removed between first floor and second floor) the variation in bending moment shows that the bending moment is maximum in floating column 1(column removed between first floor and second floor) the bending moment increases by $10.25 \%$ for $\mathrm{G}+3$ (normal column)to G+3(floating column) structures and $12.82 \%$ for $\mathrm{G}+3$ (floating column) to $\mathrm{G}+3$ ( floating column1)structures in column1(column for ground floor) and in column2(column for first floor) it increases by $5.98 \%$ for $\mathrm{G}+3$ (normal column) to $\mathrm{G}+3$ (floating column)structures and $11.96 \%$ for $\mathrm{G}+3$ (floating column) to $\mathrm{G}+3$ ( floating column1)structures.

\section{REFERENCES}

[1] Behera Sukumar Seismic analysis of multistoried building[Journal]. Rourkela:[s.n.],2012. -May.

[2] A.P. Mundada and S.G. Sawdatkar Comparative Seismic Analysis of Multistorey Building with and without Floating Column[Journal]. Buldana:[s.n],2014. -October.

[3] Sreekanth Gandla Nanabala Seismic Analysis of A Normal Building and Floating Column Building[Journal]. Andhra Pradesh:[s.n],2014. September.

[4] Prerna Nautiyal Seismic Response Evaluation of RC frame building with Floating Column considering different Soil Conditions[Journal]. Bhopal:[s.n],2014. February.

[5] Pankaj Agrawal, S.K Thakkar \& R.N.Dubey, "Dynamic analysis of a damaged building on floating column”. paper no. 24, vol.39, September 2002

[6] Pratyush Malaviya, Saurav ,"Comparative study of Effect of Floating Columns on the cost analysis of a structure designed ",Volume 5, Issue 5, May-2014
[7] Srikanth.M.K, Yogendra.R.Holebagilu, "Seismic response of complex building with floating column for zone II and zone V, International journal of Engineering Research, ISSN: 2321-7758 Vol.2., Issue. 4, 2014

[8] Dr. Mohammed Y. Fattah \& Qutaiba G. Majeed," Behaviour of Encased Floating Stone Columns", Eng. \& Tech. Journal, Vol.27, No.-7, 2009

[9] Susanta Banerjee, Sanjaya Kumar Patro," Structural analysis and design" Vol:8 No:6, 2014 